\section{Release of enzymes from cell walls by an endopectate-trans-eliminase}

THE cell walls of higher plants were long regarded as essentially inert structures which functioned mainly as mechanical barriers to the expansion of protoplasts under turgor pressure and as skeletal supports in tissues. It is now known, however, that they contain a number of hydrolytic enzymes at least one of which is a hydroxyproline-rich protein ${ }^{1}$. These enzymes are often of types associated with the dynamic recycling functions of intracellular lysosomes ${ }^{2-4}$. They have usually been detected by the activity of cell wall preparations after comminution of tissues and removal of contaminating cytoplasm by washing ${ }^{1,2,5}$ or by the activity of intact or excised roots ${ }^{3.6}$. We now report on the release of wall bound enzymes from living cells by a pectic enzyme.

An endopectate-trans-eliminase (PTE) was obtained from 3-d-old soft rots of cucumbers caused by the bacterium Erwinia carotovora (NCTC 1747). One volume of rot was extracted with one volume of $0.85 \% \mathrm{NaCl}$ and made cell-free by centrifuging. Ammonium sulphate was added to $61-80 \%$ saturation, the precipitate collected, dissolved in, then dialysed against water, and fractionated by elution from Sephadex G75 superfine

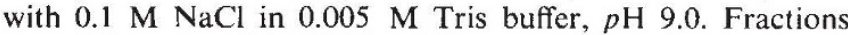
containing most of the PTE activity were subjected to isoelectric focusing between $p \mathrm{H} 7.0$ and 10.0 for $52 \mathrm{~h}$ at $4^{\circ} \mathrm{C}$. Fractions containing PTE were combined, dialysed and gave a single band after electrophoresis on polyacrylamide gel. The preparation did not degrade any of a wide range of cell wall and other polymers other then those based largely on anhydrogalacturonic acid residues. One unit of activity of this PTE gave an increase in

Table 1 Effect of endopectate-trans-eliminase (PTE) on release of $\mathrm{K}^{+}$and enzymes from potato luber tissue

Activity $\dagger$

\section{Treatment*}

\begin{tabular}{lrrrrrr} 
& $a$ & $b$ & $c$ & $d$ & $e$ & $d+e$ \\
$\mathrm{~K}^{+}$ & 625 & 17 & 685 & 715 & 60 & 775 \\
Acid phosphatase & 0.132 & 0.059 & 0.056 & 0.040 & 0.121 & 0.161 \\
Phenoloxidase & 0.13 & 0.032 & 0.059 & 0.046 & 0.12 & 0.166 \\
Peroxidase & 0.10 & 0.060 & 0.023 & 0.008 & 0.083 & 0.091 \\
Malic dehydrogenase & 0.132 & 0.082 & 0.115 & 0.052 & 0.22 & 0.272 \\
\hline
\end{tabular}

Values shown are corrected for slight changes caused by autoclaved enzyme.

${ }^{*} a, 3 \mathrm{ml}$ water containing 14.8 units PTE, $0.001 \mathrm{M} \mathrm{CaCl}_{2}, 0.02 \mathrm{M}$ Tris buffer $(p \mathrm{H} 9.0)$ for $3 \mathrm{~h}$ at $22^{\circ} \mathrm{C} ; b$, as $a$ but in $0.5 \mathrm{M}$ sucrose as plasmolyticum; $c$, as $b$, then liquid removed, disks washed in $0.5 \mathrm{M}$ sucrose, added $3.0 \mathrm{ml}$ water for $10 \mathrm{~min} ; d, 3 \mathrm{ml}$, frozen at $-20^{\circ} \mathrm{C}$, thawed and kept for $10 \mathrm{~min}$; $e$, liquid removed, disks then treated as $a$.

$\dagger \mathrm{K}^{+}$activity by flame photometry (p.p.m.). Acid phosphatase by estimating $p$-nitrophenol liberated from $p$-nitrophenyl phosphate at $400 \mathrm{~nm}$ (ref. 7); activity was expressed as $\mathrm{mg} p$-nitrophenol liberated per $0.2 \mathrm{ml}$ enzyme solution. Phenoloxidase by estimating oxidation of catechol $^{8}$; activity was expressed as $\triangle O D 495 \mathrm{~nm} \mathrm{~min}^{-1}$ per $0.2 \mathrm{mI}$ enzyme solution. Peroxidase by estimating oxidation of pyrogallol in the presence of $\mathrm{H}_{2} \mathrm{O}_{2}$ (ref. 9); activity was expressed as $\triangle O D 420 \mathrm{~nm}$ $\mathrm{min}^{-1}$ per $0.01 \mathrm{mil}^{2}$ enzyme solution. Malic dehydrogenase by estimating oxidation of NADH in the presence of oxalacetic acid ${ }^{10}$; activity was expressed as $\triangle O D 340 \mathrm{~nm} \mathrm{~min}{ }^{-1}$ per $0.1 \mathrm{ml}$ enzyme solution.

absorbance at $550 \mathrm{~nm}$ of 0.1 in $30 \mathrm{~min}$ at $25^{\circ} \mathrm{C}$ in the following assay: $1 \mathrm{ml}$ enzyme solution, $2.5 \mathrm{ml} 1 \%$ sodium polypectate (Sunkist Growers Inc.), $0.5 \mathrm{ml} \mathrm{CaCl}{ }_{2}$ (final $0.001 \mathrm{M}$ ), Tris buffer, $p \mathrm{H} 9.0$ (final $0.1 \mathrm{M}$ ), left at $25^{\circ} \mathrm{C}$. Then $7.5 \mathrm{ml}$ of a mixture of $5 \mathrm{ml}$ thiobarbituric acid $(0.04 \mathrm{M})$ and $2.5 \mathrm{ml} \mathrm{HCl}$ (1M) was added and the red colour produced estimated at 550 $\mathrm{nm}$ against a reagent blank.

Samples of 48 disks $(0.5 \times 7.0 \mathrm{~mm}$ diameter $)$ from medulla of turgid potato tubers (cv. Majestic) were treated in various ways.

At the end of each treatment, the ambient liquid was collected and assayed for $\mathrm{K}^{+}$, acid phosphatase, phenoloxidase, peroxidase and malic dehydrogenase.

The $3 \mathrm{~h}$ treatment of tissues with PTE caused cell separation and death of protoplasts in the sense that they did not plasmolyse in hypertonic solutions; treatment with enzyme in a plasmolyticum still caused cell separation but protoplasts remained plasmolysed and intact.

Table 1 summarises the effects of the different trcatments and also shows in column $d+e$ the total of $\mathrm{K}^{+}$and enzymes liberated from frozen tissue after thawing and released from residual tissue after treatment with PTE for $3 \mathrm{~h}$. Comparison of columns $d$ and $e$ show that $\mathrm{K}^{+}$liberated by PTE treatment of residual tissue was only about $10 \%$ of that liberated by freezing followed by thawing. The corresponding figures for the enzymes were $72-91 \%$.

Similarly, although very little $\mathrm{K}^{+}$was released from tissues treated with PTE in a plasmolyticum, large amounts of peroxidase, acid phosphatase and malic dehydrogenase and smaller though substantial amounts of phenoloxidase were liberated in these conditions. There were corresponding differences when plasmolysed protoplasts in PTE treated tissue were rapidly deplasmolysed.

Because PTE is believed to act only on substrates in cell walls and middle lamellae, the results suggest that large proportions of the four enzymes in cells are bound to cell walls and are liberated when these are exposed to PTE. This confirms earlicr work which showed that cell walls contain substantial amounts of peroxidase ${ }^{1}$ and acid phosphatase ${ }^{5}$ but is unexpected for malic dehydrogenase (which is known to occur as different isoenzymes in mitochondria, chloroplasts and cytoplasm" ${ }^{\text {"l }}$ but not, so far as we know, outside the plasmalemma).

We have considered the possibility that our results could be explained, at least in part, by adsorption by cell walls of cytoplasmic enzymes released when cells are broken during preparation of the potato tuber disks or by residual cytoplasm on cut surfaces. But this seems unlikely because preliminary washing of disks in $0.2 \mathrm{M} \mathrm{NaCl}$ did not decrease release of acid phosphatase or malic dehydrogenase when disks were later treated with PTE in a plasmolyticum. It seems, therefore, that these four enzymes are released from cell walls by the action of PTE which is highly specific and is believed to be confined to the rupture of $\alpha-1,4-\mathrm{D}-$-glycosiduronic linkages. This poses the question of the relationship between polymers based on these linkages and wall-bound protein and, of course, the function of wall-bound enzymes particularly such as malic dehydrogenase hitherto regarded as essentially cytoplasmic.

This work was supported by the Science Rescarch Council.

\section{G. J. Stephens \\ R. K. S. WOOD}

Botany Department, Imperial College, London SW7 2AZ, UK

Received June 3; revised July 25, 1974.

'Ridge, I., and Osborne, D. J., Nature new Biol., 229, 205-208 (1971).

${ }^{2}$ Kivilaan, A., Beaman, T. C., and Bandurski, R. S., Pl. Physiol., Lond. 36, 605-610 (1961).

${ }^{3}$ Chang, C. W., and Bandurski, R. S., Pl. Physiol., Lond., 39, 60-64 (1964).

${ }^{4}$ Hall, J. L., and Davie, C. A. M., Ann. Bot., 35, 849-855 (1971)

${ }^{5}$ Lamport, D. T. A., and Northcote, D. H., Biochem. J., 76, 52p (1960).

${ }^{6}$ Hall, J. L., and Butt, V. S., J. exp. Bot., 19, 276-287 (1968).

${ }^{7}$ Pitt, D., and Galpin M., Planta, 101, 317-332 (1971).

${ }^{8}$ Maxwell, D. P., and Bateman, D. F., Phytopathology, 57, 132-136 (1967).

${ }^{9}$ Lobenstein, G., and Linsey, N., Phytopathology, 51, 533-537 (1961).

${ }^{10}$ Worthington Enzyme Manual, 11, (Worthington Biochemical Corporation, Freehold, N.J., 1972).

${ }^{11}$ Mukerji, S. K., and Ting, I. P., Archs Biochem. Biophys., 131, 336-351 (1969). 